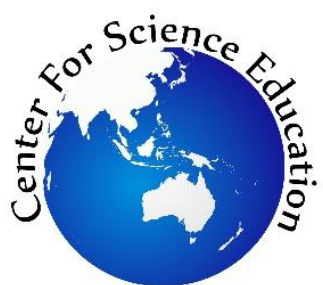

Tersedia online di EDUSAINS

Website: http://journal.uinjkt.ac.id/index.php/edusains

EDUSAINS, 11 (2), 2019, 249-254

Research Artikel

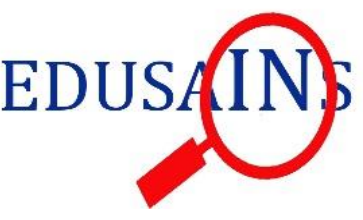

\title{
THE ANALYSIS OF STUDENT'S WRITTEN COMMUNICATION SKILLS IN SCIENCE LEARNING BASED ON GENDER IN THE MIDDLE SCHOOL IN SOUTH TANGERANG REGION
}

\section{ANALISIS KETERAMPILAN KOMUNIKASI TERTULIS SISWA DALAM PEMBELAJARAN ILMU PENGETAHUAN ALAM (IPA) BERDASARKAN GENDER DI SEKOLAH MENENGAH DI WILAYAH TANGERANG SELATAN}

\author{
Hariyanto, S Yamtinah, Sukarmin, Sulistyo Saputro, L Mahardiani \\ Sebelas Maret University, Indonesia \\ haryhariyanto@ student.uns.ac.id
}

\begin{abstract}
Abstrak
Keterampilan komunikasi tulisan merupakan keterampilan yang sangat penting didalam era globalisasi dan termasuk kedalam salah satu keterampilan belajar abad 21 yang harus diberdayakan dalam pembelajaran. Penelitian ini bertujuan untuk komunikasi tulisan peserta didik secara real di sekolah berdasarkan gender. Subjek dalam penelitian ini berjumlah 186 orang dengan rincian 88 orang laki-laki dan 98 orang perempuan. Metode yang digunakan dalam penelitian ini adalah metode penelitian deskriptif kuatitatif. Instrumen penelitian yang digunakan berupa lembar observasi dan pedoman wawancara. Data yang didapatkan kemudian dianalisis secara kuantitatif sehingga didapatkan nilai keterampilan komunikasi peserta didik. Hasil penelitian mengungkapkan tidak terdapat perbedaan yang terlalu besar antara nilai keterampilan komunikasi tulisan peserta didik laki-laki dan perempuan. Masing-masing gender(laki-laki dan perempuan) mendapatkan rata-rata nilai 1,44 dan 1,45, namun keduanya masih masuk kedalam kategori nilai huruf D+. Nilai keterampilan komunikasi tulisan peserta didik masih relative rendah dengan nilai rata-rata 1,44 $(D+)$. Hasil ini masih jauh dibawah standar pemerintah dalam Permendikbud No. 104 tahun 2014 yaitu 2,67 (B-) untuk aspek keterampilan. Hal tersebut mengindikasikan perlu ditingkatkannya pelatihan keterampilan komunikasi didalam pembelajaran.
\end{abstract}

Kata Kunci: Keterampilan Komunikasi; komunikasi verbal; Komunikasi verbal non-vocal; komunikasi tulisan; Komunikasi tulisan berdasarkan gender

\section{Abstract}

Written communication skills are essential for the globalization era, and it is one of the 21 st-century skills that must be empowered in learning. This study aimed to determine the profile of learners' written communication skills in real terms by gender. The subjects in this study were 186 students, consisted of 88 male and 98 female students in detail. The method used in this research was a descriptive-quantitative research method. The research instrument used was an observation sheet and the form of an interview. The data obtained were then analyzed quantitatively so that the value of the students' communication skills was appropriately obtained. The results of the study had found that there were not too differences in the mean values of male and female written communication skills. Each of them got an average score of 1.44 and 1.45 , but both are still in the $\mathrm{D}+$ category of value. The value of the students' written communication skills was still relatively low, with a value of 1.44 , interpreted as a D+ category. The results were far below government standards as regulated in the Minister of Education and Culture No. 104 of 2014, which is equal to 2.67 (B-). Further study is needed to improve training in students' written communication skills in learning.

Keywords: Communication skills; verbal communications; non-vocal verbal communication; written communication; written communication by gender

Permalink/DOI: http://doi.org/10.15408/es.v11i2.11320 


\section{INTRODUCTION}

Communication is one of the inevitable learning skills that are indispensable in the 21st century (Triling \& Fadel, 2009). These skills open up opportunities for every individual to be able to collaborate individually or in groups. Communication skills not only serve as a means of delivering information but also play a role in all lines of life. This is consistent with the opinion issued by the Director of Human Resources of PT Angkasa Pura in Gloria (2018) which states that prospective undergraduate students must enhance and equip themselves in the face of the world of work. One of the things that can be done to achieve this is by increasing communication skills. This opinion is also supported by the Indonesian skill report (2010) which states that the skills that are needed by workers in Indonesia are communication skills. The report was strengthened by the results of the Mckinsey Global Institute survey which stated that one of the reasons for difficulty in fulfilling one's job qualifications was the lack of communication skills. These things illustrate the importance of communication skills, especially interpersonal and group skills in the world of work (Bahri, 2018).

Adler and Rodman (2006) divide communication skills into several types namely verbal and nonverbal, as well as vocal and nonvocal. Verbal communication skills are skills that can be seen based on the use of communication symbols, while non-verbal communication is communication skills based on a communicator's body language. Both types of communication are distinguished based on how they are delivered. A vocal type of verbal communication means communication-related to communication symbols in the form of language that is conveyed orally (orally). Types of non-vocal verbal communication delivered in written form (written). The next type is non-verbal vocal and non-vocal communication types. Vocal non-verbal communication can be observed from the quality of vocals, intonation, and so forth. Conversely, non-verbal communication non-vocal leads to the observation of gestures and body language.
These types of communication are very necessary for life. Therefore we need the means to train these skills in the community. The most relevant container or means for realizing this skills training is to make it happen in the world of education (Chaeruman, 2009). The form of government attention related to the importance of improving skills, especially communication skills is to spark three main components of the 2013 curriculum compilers. The three main components are knowledge, skills, and attitudes. These components are the main demands of the 2013 curriculum. The government expects an emphasis on increasing the skills component in the 2013 curriculum to produce students who are knowledgeable, skilled and of good character.

Specifically, this study looked more closely at the types of verbal communication skills on a non-vocal basis. The main reason for this observation is the need for students who are proficient in communicating in writing is increasing. That is, students can not only communicate skillfully using verbally but also by writing. This is based on the role of communication itself in learning, especially science learning. Communication has the role of the means of disseminating knowledge. Kurniawan (2011) states that there is a close relationship between communication skills and science learning. This is based on the nature of science which aims to equip a student with the ability as a researcher or scientist whose task is to produce research, ideas, and ideas. The output of the task of a scientist is later communicated to a wide audience in various forms of media.

Another reason the focus of research on students' writing communication skills is based on real conditions in the field which indicate that there are still minimal scientific journals published or written by researchers in Indonesia (Pramisti, 2016). On a ratio basis, one accredited scientific journal in Indonesia is used by 410 thousand people, while Singapore is only used by 200 people. This condition clearly shows the lack of internationally accredited and internationally recognized scientific journals in Indonesia. Indonesia ranks 52nd out of 229 
countries. The rating then rose in 2018 over Singapore and Thailand but was still below Malaysia (Fatimah, 2018).

The above conditions should be a serious concern if Indonesia is to become one of the worlds' research mecca. The most likely thing to do is to prepare young people who are ready to conduct research and publications. Training on this is possible by applying the training to the world of education. One of the most likely things is to empower students' skills in communication, especially non-vocal verbal communication (written). Matters related to how to improve and field conditions regarding these skills will not be seen without the existence of research that specifically reveals a picture of students 'written communication skills. Also, the written communication skills observed are based on the participants' gender. The results of research on written communication skills based on gender are considered important because basically communication skills possessed by students must be the same as not fixated on gender. Therefore, this study aims to express students' written communication skills in real terms at school based on gender. The observations will then be used as results in finding causes and solutions to overcome the lack of communication skills of students' writing. This, of course, is done if the observations show low skills.

\section{METHOD}

This research uses descriptive research method. Descriptive research is the most basic research and is used to describe real conditions in the field without any manipulation from researchers or observers. The subjects of this study were 186 people consisting of 88 male and 98 female students. The subjects of the study were the eighthgrade students of SMP divided into five classes. Observations were carried out by analyzing documents of students' student reports without any manipulation of the research subjects in five different classes. Data collection instruments in this study were observation sheets and interview guidelines. Observations were made by two observers in each class to minimize the subjectivity of the researcher. The data that has been collected is then analyzed quantitatively and described qualitatively.

\section{RESULTS AND DISCUSSION}

The results in this study are the value of written communication skills obtained by students based on the analysis of reports that have been written. Reports on the results of experiments that have been compiled by students are then observed based on aspects of observation of written communication skills. There are five aspects of observation of written communication skills, namely: 1) presenting observational data, 2) making discussions following with observations, 3) making conclusions following with observations, 4) providing suggestions related to observations, and using report writing rules following with EBI (Indonesian spelling). The results of observations of written communication skills are generally presented in Figure 1.

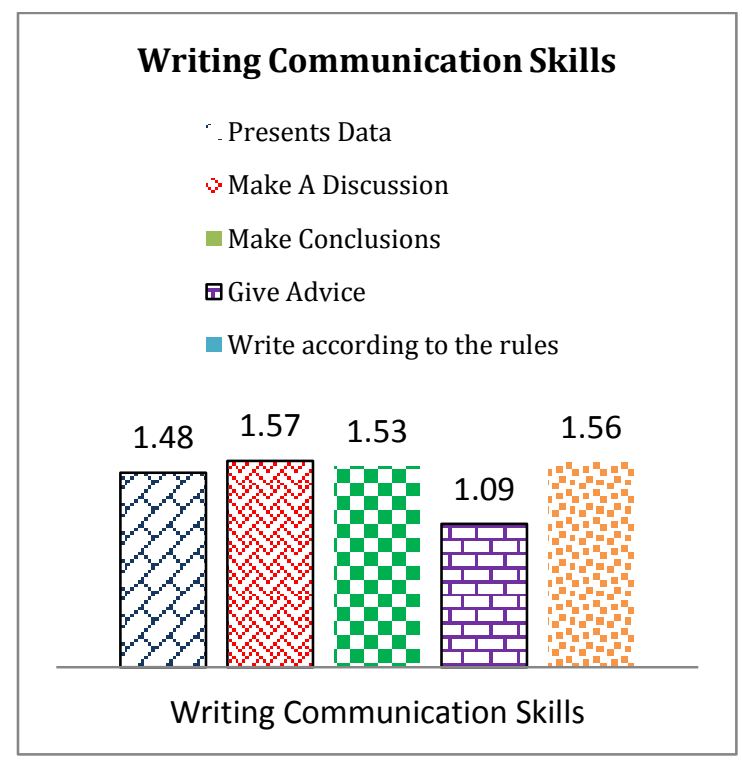

Figure 1. Students' Written Communication Skills Pattern

Figure 1 illustrates that the aspect with the highest value of observed written communication skills is discussion skills. Not much different from the skills to make discussion, the students' writing communication skills in writing according to EBI rules are also quite high compared to other aspects. Instead, the lowest observed aspect of 
written communication skills is the skill in giving advice. The aspect of giving advice is classified as low due to several reasons, one of which is the difficulty of students in providing the latest ideas related to the results of practicum as outlined in the report. This can indicate that communication skills need other skills that need to be improved to empower communication skills. If seen from the conditions above, it can be assumed that communication skills also require students' skills in critical and creative thinking following the demands of the 21 st century. The statement is in line with the results of Nuryati (2016) study which states that the communication skills of students can be influenced and affect other skills as well as critical and creative thinking skills and problemsolving.

In general, Figure 1 also illustrates that all aspects of written communication skills are still below the standards set by the government in Permendikbud No. 104 of 2014 which is 2.67. This condition can be caused by several things, namely: 1) the lack of trained students in making writing, 2) the teacher rarely requires students to write, and 3) the lack of training in making scientific writing in the school environment. This should no longer happen.

The 2013 curriculum, in this case, has mandated teachers to be able to use learning models which in the result demands students in making or compiling reports. This is in line with the results of research Sufairoh (2016) which states that the 2013 curriculum requires learning student-centered methods. The learning models include Project Based Learning (PjBL), Problem Based Learning, and Cooperative Learning. These three learning models ultimately require students to report the results of observations or explorations made in the form of reports.

The cause of the low aspect of every observation of students' written communication skills was revealed based on the results of the interview. The aspect of presenting data gets below standard value because students are not accustomed to presenting data in the form of tables or graphs independently. Learners feel confused about how to organize the data obtained in the form of tables or graphs. This is in line with research results by Putri et al (2016) which states that students are only accustomed to filling in observational data in the tables that have been provided. Therefore students feel not used to presenting data in the form of tables or graphs independently.

The next aspect is the aspect of making discussions correctly and making conclusions. These two aspects are also still below the government standard for skills, which is 2.67. The results of the interview revealed that students were confused in discussing the results of observations. Also, students feel unable to conclude the results of the practicum carried out. Both of these are caused by the lack of training of students in discussing and summarizing the results of the activities carried out.

The last two aspects observed were also still below the standard value of skills set by the government. Aspects of giving advice and writing with EBI still get low marks based on observations. The results of this study are in line with the research results of Putri et al (2016) which states that training in the aspect of written communication is still very rarely done by teachers. Students are usually only asked to answer questions related to learning activities such as practicum without being given reinforcement regarding important material contained in these activities. This makes students less trained in discussing and summarizing the results of learning activities. The training has also never been given by the teacher regarding writing which is following with EBI and writing suggestions that are appropriate to the learning context.

In addition to observing written communication in general, this study also revealed the results of research on written communication skills based on gender. More clearly, the written communication skills of students observed in this study are presented in Figure 2. 


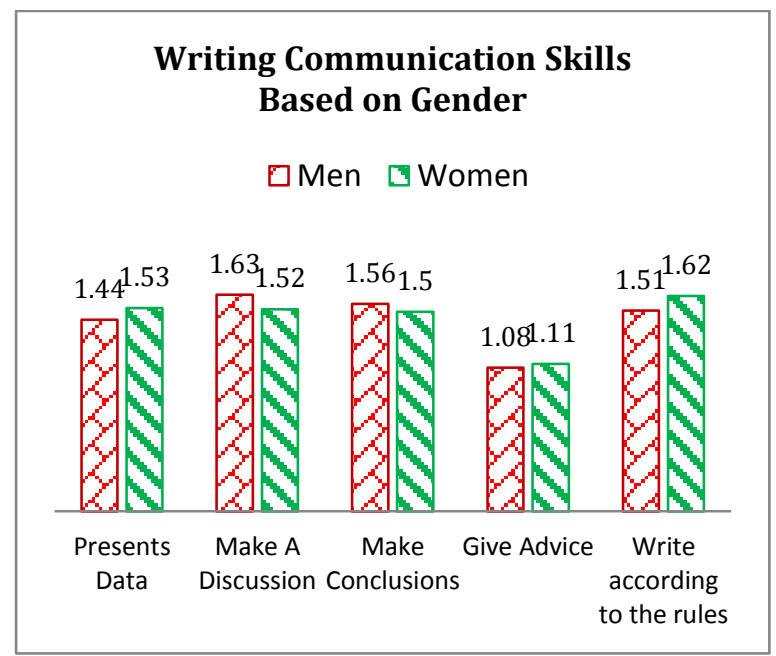

Figure 2. Differences of Students' Written

Communication Skills by Gender

Figure 2 illustrates that students' written communication skills based on gender do not have too much difference. The average value of the communication skills of male and female students is 1.44 and 1.45 , respectively. The difference between the two is only 0.1 and the value does not make a significant difference. Nevertheless, the results of the study revealed several of things that distinguish the written communication skills of female and male students.

The results showed that the average value of the communication skills of female students was slightly better when compared to men. This is because female students are more active in several ways, namely: 1) presenting data, 2) giving advice, and 3) writing according to EYD rules. This result is in line with previous research which states that women's oral and written communication skills are better than men (Wijaya et al., 2016). Also, the results of this study were strengthened by the observations of Elliott et al who said that the verbal abilities of female students were more accurate and detailed while male students were more critical in various interpretations (Sari, 2015).

Male students generally do have lower written communication skills compared to female students. However, several aspects that show that male students are superior to female students. These aspects include making discussions and making conclusions. Male students have written communication skills in the aspect of making discussions better than women. This is contrary to the results of research by Wijaya et al (2016) which states male subjects tend to be inaccurate and not detailed in expressing ideas in written media.

This phenomenon can be viewed from the scoring criteria used. The assessment rubric for the discussion aspect for the highest score is "making the discussion following with the observations clearly and easily understood". Male students, in this case, tend to make a discussion that is very following with the results of observation without re-writing the work steps in the discussion. While women discuss by re-writing the work steps without focusing on the results obtained. This indicates that basically, the anomaly that occurs is not due to a shift in the characteristics of male students.

However, differences in communication skills based on gender cannot be generalized clearly. Researchers now realize that differences in students' mathematics learning outcomes that are influenced by gender differences are not absolute, often confused, this is also influenced by their socioeconomic background. Furthermore Gross and Thompson (2007) concluded that in general gender differences in communication skills depend on the content of learning, the nature of the knowledge and skills assigned, and the conditions at which learning is carried out.

\section{CONCLUSION}

This section consists of conclusions and suggestions. The conclusion presents a summary of the description of the results and discussion that refers to the purpose of the study. Based on these two points, new ideas are developed which are the essence of research findings, not statements of hypotheses as a result of the analysis. While suggestions are based on the research findings discussed. Suggestions can refer to practical actions, the development of new theories, and / or further research.

\section{Acknowledgment}

Thanks to Mrs. Dwi Puji Astuti, S.Pd. for permitting and allowing her class to be the subject 
of observing communication skills under the consent.

\section{REFERENCES}

Adler, R., \& Rodman, G. 2006. Understanding Human Communication. New York: Oxford University Press.

Bahri, N.A. 2018. Peran Komunikasi Antar Pribadi pada Lingkungan Kerja dalam Perspektif Islam. Jurnal Ilmu Sosiologi Agama, 1 (1): 128-142.

Chaeruman. A. U. 2009. Pembelajaran Interaktif dengan Memanfaatkan Aneka Sumber Belajar. Pusat Teknologi Komunikasi Departemen Pendidikan Nasional. Jakarta: Kemdiknas.

Fatimah, S. 2018. Salip Singapura, Publikasih Ilmiah Indonesia Peringkat 2 Asean. Dikutip dari:

https://news.okezone.com/read/2018/04/11/6 5/1885240/salip-singapura-publikasi-ilmiahindonesia-peringkat-2-asean , pada tanggal 19 April 2019.

Gloria.2018. Kemampuan Komunikasi Penting untuk Masuki Dunia Kerja. Dikutip dari: https://ugm.ac.id/id/berita/16922-

kemampuan.komunikasi.penting.untuk.masu ki.dunia.kerja, pada tanggal 17 April 2019.

Gross, J.J. \& Thompson, R.A. 2007. Emotion Regulation: Conceptual Foundation. Handbook of Emotion Regulation, (eds.) James J. Gross. New York: Guilford Publications.

Indonesian Skills Report. 2010. Trens in Skills Demand, Gap, and Supply in Indonesia. Report No. 54741-EAP.

Kurniawan, A. T. 2011. Konsep Komunikasi Ilmiah Dalam Pemanfaatan Informasi di Perpustakaan dan Dokumentasi. Jurnal Komunikasi Massa, 4 (1): 12-22.
Mckinsey Global Institute. 2011.Big Data: The Next Frontier for Innovation, Competition, and Productivity. Report. No. 76889.

Nuryati. 2016. Peningkatan Kemampuan Komunikasi dan Berpikir Kritis Melalui Model Kooeperatif STAD dan MURDER. Jurnal Pengajaran MIPA, 21 (1): 9-13.

Pramisti, N.Q. 2016. Muramnya Dunia Riset Indonesia. Dikutip dari: https://tirto.id/muram nya-wajah-dunia-risetindonesia-bsF6, pada tanggal 19 April 2019.

Putri, A., Enawaty, E., Lestari, I. 2016. Deskripsi Keterampilan Komunikasi Siswa SMA Negeri 9 Pontianak Melalui Metode Praktikum pada Materi KSP. Jurnal Pendidikan dan Pembelajaran IPA. 5(9): 111

Sari, R. 2015. Aktivitas Metakognisi dalam Memecahkan Masalah Matematika Ditinjau dari Gender Siswa Kelas VII SMP Negeri 1 Nanggulan Kabupaten Kulon Progo. Tesis S2 PPS Universitas Sebelas Maret. Surakarta. (Unpublished).

Sufairoh. 2016. Pendekatan Saintidik dan Model Pembelajaran K13. Jurnal Pendidikan Profesional. 5 (3): 12-21.

Triling \& Fadel. 2009. 21 $1^{\text {st }}$ Century Skills: Learning for Life in our times. San Fransisco.

Wijaya, H.P.I., Sujadi, I., \& Riyadi, R. 2016. Kemampuan Komunikasi Matematis Siswa Sesuai Gender Dalam Pemecahan Masalah Pada Materi Balok dan Kubus. Jurnal Elektronika Pembelajaran Matematika, 2 (9) 778-788. 